\title{
INFORMATION WARS' PATHOGENIC TEXTS NEUTRALIZATION ALGORITHM
}

The article deals with studying the negative effect of the speech influence phenomenon realized within the pathogenic texts distributed in the network of the information wars in the Ukrainian information space. The research is carried out within the paradigm of such modern complex sciences as Neuro-Linguistic Programming and Suggestive Linguistics, and is a stepby-step algorithm of the pathogenic texts' negative effect neutralization based on isolating the suggestive techniques' markers having been described in NLP's Meta-model, P. Ekman's Lies Theory, and the author's information wars classification, as well as the Linguistic Suggestivity NAP-structure.

Key words: information war, influence, speech influence, suggestion, NeuroLinguistic Programming, NLP, Suggestive Linguistics, Lies Theory, Language Meta-model, pathogenic texts, algorithm, Linguistic Suggestivity NAP-structure.

The information wars (IWs) have truly become one of most wide-spread information technology, possessing the attribute of totality most of the other warfare types lack, since, 
unlike the territorial borders, there are no clear borders in the world information space, and any information might circulate freely all around the world, if managed correctly. Originally, the IW concept has been enshrined in the US Defense Ministry's Directive DOD S 3600.1 of December 21, 1992, where it has been used in a narrow sense, and considered as a radioelectronic fight type. Subsequently, a "strategic information war (informational confrontation)" term appeared for the first time in the American "Rand" Corporation's MR661-0SD «Strategic Information Warfare. A New Face of War» (1996) report [10]. It was defined as a war with the use of the state global informational space and infrastructure aimed at holding strategic military operations, and strengthening the influence on one's own informational resource. As of now, the Ukrainian researchers N. Prisyazhnyuk and Y. Zharkov define the IW as "a complex of interrelated and goals-, location- and time-agreed activities, oriented on reaching an informational dominance" [ibid]. The IW is aimed at weakening the opponent's or competitor's moral and material resources while strengthening one's own. It provides for the propaganda affecting the individual's conscience within the ideological and emotional spheres, aimed at manipulating the masses. Usually, such a manipulation is directed at:

- introducing the hostile, harmful ideas and views to the social and individual conscience;

- masses' disorientation and disinformation;

- weakening particular beliefs and foundations;

- intimidating one's own people with the image of the enemy;

- intimidating the enemy with one's might;

- providing the market for one's economy (but in this case, the IW is a part of a competition).

As a rule, the scientists distinguish the following types of IW:

- psychological war;

- cyber war;

- network war;

- ideological diversion;

- radio-electronic fight, which can manifest itself in the following ways:

- TV and radio broadcasting might be suppressed;

- TV and radio broadcasting resources might be captured / conquered in order to hold a disinformation campaign;

- communication networks might be blocked or unavailable;

- stock market operations might be sabotaged via an electronic interference in order to provide a sensitive information leak, or spreading disinformation [ibid].

Usually, local or formally technical dominant being the basic criteria of such classifications, leaving the linguistic component as the informational destruction dominant, and its suggestive specificity out of the researchers' attention range, even though it would have given an opportunity to precisely identify the pathogenic elements of such information, and, thus, reduce its consequences. In this aspect, the approach we offer would also stipulate for a substantial widening of the existing IW's classification, since we consider their deep, 
natural components (untruthful, destructive information usage, and a mandatory suggestive effect being the crucial ones), which could only be identified with the synthesis of the brand new research methods and methodologies, including NLP, Suggestive Linguistics and Lies Theory, because these sciences study the suggestive, scilicet the influential side of any information, where speech could be considered as a totally suggestive phenomenon with potentially suggestive components, and the language's embodiment form - as a text in broad sense (verbal and non-verbal). Besides, the IW's main goal, which is to support or change the addressee's preferences, implies the objective reality's interpretation's non-identity and distortion, as its fundamental attribute. Suchwise, these science's essential provisions would allow to identify the basic segments of the IW as the modern communicative space's immanent component, what defines the relevance of this work, aimed at constructing the information wars paradigm's pathogenic texts' negative effect neutralization algorithm. The pathogenic texts distributed in the network of the information wars are the object of the work, while these texts' suggestive mechanisms are the subject. The texts distributed in the Ukrainian information space in the network of the information wars (over 100 news texts units having been collected in 2014 - 2018) became the factual base of the research. The basic research methods having been utilized in the work are represented by the general analysis and synthesis methods, descriptive method and quantitative analysis, as well as a row of special methods, i.e. the linguistic modelling method, component analysis elements, Milton- and Metamodel identification methods, as well as the Object-Oriented and Structured Programming, and General Logics ones (proof and refutation).

In the previous works, we offered a brand new complex approach to classifying the IWs, which is based on the fact that the text semantics of any IW correlates with the particular elements of the Metamodel of Language (MML) introduced by R. Bandler and J. Grinder in the network of NLP, and the types of lies according to P. Ekman's Theory of Lies [see 15, 17]. Having compared the R. Bandler and J. Grinder's MML elements, and P. Ekman's lies types, with the elements present in the IW discourses having been analyzed, we suggested identifying the following IWs types:

1. "Swan Lake". This IW type is comparable to deletion MML process and concealment lies type, when the important parts of information are neglected, scilicet overlooked, and only the incomplete, partial data concerning the particular informational occasion (event) is presented (that is, only a part of the event which is important for the mass media's informational policy, without all the details is highlighted in the mass media). I.e., the Soviet Militia Day has always been festively celebrated in the USSR on November 10, with the Soviet pop stars' concert aired on the TV in the evening. However, in 1982, the concert was cancelled, and "The Swan Lake" ballet was aired instead of it, making the ordinary citizens assume that something went wrong in the country. It turned out that Leonid Bryezhnyev died, and since then, the music from "The Swan Lake" became a peculiar "phonogram" not only for his funeral, but also for those of his successors Yuri Andropov and Konstantin Chernyenko, and has always been used to conceal some information and prevent the ordinary citizens' access to it. 
2. «Mountains out of Molehills». This IW type is comparable to generalization MML process and exaggeration lies type, when the original data is formidably exaggerated / diminished in order to create a particular informational effect (i.e., a noticeable exaggeration or lessening of the number of the people present at a particular demonstration). I.e., during the demonstrations on Kyiv's Maydan, the Ukrainian mass media reported that over 100000 people have been present there, and some of their Russian colleagues ("NTV", " $1{ }^{\text {st }}$ Channel", "Life News" etc.) conveyed that there have only been $2000-3000$ participants, what has surely well been caused by the need to artificially lessen the number of the demonstrators, and, subsequently, the significance of the event.

3. "Fake Attack". This IW type is comparable to the distortion MML process, and falsification lies type, when the knowingly false information about a particular informational occasion is delivered (i.e., "invented" news, created for an artificial pressure escalation in the state's informational space, and destabilizing the situation). As an example, we can cite the "famous" fake news by the Russian mass media (July 12, 2016) about a boy having been allegedly crucified in Slavyansk city, told by an alleged witness of this event. The information hasn't been backed up by any facts, but aroused great indignation in Russia. Only in December, the " $1{ }^{\text {st }}$ Channel" TV presenter announced that the journalists didn't and don't have any proofs for this story.

Ergo, having outlined the basic information wars types, we consider it necessary to suggest the according information wars paradigm pathogenic texts' negative effect neutralization algorithm. This three-stage algorithm is based on the postulates of NLP, Suggestive Linguistics, and Lies Theory, as well as on the general provisions of Logics and Object-Oriented and Structured Programming, and thus, could be represented as an according flowchart illustrating a solution model to a given problem. It has to be noted that involving the provisions of Object-Oriented Programming, which is «a programming methodology based on presenting a program as a set of objects, each of which is an instance of a particular class, while the classes form an inheritance hierarchy» [see 2], would make it possible to create a formalized and maximally precise identification of the pathogenic texts, as well as to attribute them to the according information war type. In addition, the provisions of Structured Programming - «a software development methodology based on the program representation as a hierarchical blocks structure» [see 6] would allow to formulate the flowcharts structure to visualize the suggested algorithm.

So, the aforementioned algorithm (hereinafter - ICN-algorithm) consists of three control structures - successive blocks:

1. Identify - the block of identifying the pathogenic texts' construct markers, which is executed with the help of involving the NLP Metamodel analysis method;

2. Classify - the block of classifying the abovementioned construct markers and attributing them to the according information war type;

3. Neutralize - the block of choosing the reaction activity to be carried out in order to neutralize of maximally lessen the according pathogenic text's negative effect.

Executing the $1^{\text {st }}$ block actions stipulates for a pathogenic text analysis in the network of the Metamodel of Language having been developed in NLP and Suggestive Linguistics 
paradigm, P. Ekman's Theory of Lies, as well as the suggestive texts' lexical-semantical NAP-structure, which determines the need of a brief description of these concepts.

According to R. Bandler and J. Grinder, the Metamodel of Language is "an explicit representation or description of our unconscious behavior, subordinate to the rules" [3, p. 50], and describes "the transmutation of the human's experience's deep structure into a verbalized surface structure" [11, p. 152], and is realized in three processes, universal behavior laws: deletion, generalization and distortion [see 3]:

1. Deletion process, which expresses the message's important parts' reduction, linguistically represented by such markers as:

- comparative-superlative construction with the omitted comparison object, which reduce the general logic of the statement, and transpose it into the non-dominant interpretation plane;

- judgements (referential indexes) - words which are used while omitting "the nominal arguments, procedural words or verbs in the in-depth structure" [3, p. 100], so that the statement starts to possess a subjective modality, its argumentative evidence all but wiped out;

- nominalizations - cases when "a verb which originally described a lengthy process is turned into a noun" [9, p. 125], thus changing the local dynamics of the sentence into a static informational content;

- unspecified vocabulary (unspecified verbs represented by passivized forms and non-absolute verbs models, and nouns represented in two forms: ones without a reference index, and ones with specific semantic filling), which, with its inner potential, doesn't open the semantic positions required for a full understanding of the lexeme, or causes a maximally subjective interpretation on the lexeme's sense dominants.

2. Generalization process, when "all the elements of the model that belongs to a particular individual get torn away from the initial experience, that has created these models, and start representing a total category, with this experience being a singular case" [1, p. 30], linguistically represented by:

- universal quantifiers - "pronoun nominae with unspecified personal characteristics" [8, p. 165] and "adverb indexes which cause a local-temporal conceptualized generalization " [ibid];

- modal operators of possibility / necessity, which "set the limits outlined by unspoken rules" [9, p. 127], and are realized via almost every modality-marked part of speech.

3. Distortion process, which means " verbalization of the hypothetically modeled environment with the components not having been identified in the previous experience " $[8$, p. 168], linguistically represented by:

- complex equivalence - which is "connected with the surface structures that are equivalent to each other within the patient's model" [3, p. 129], and is usually represented by complex sentences (or their elliptical models) with the subordinate clauses of condition and reason; 
- presuppositions, which are "a deep assumption which is necessary for the representation to be reasonable" [ibid, p. 277-278], and most often act as the externalized nomenae, even though such textual presuppositions could also possess a hidden, latent purport, creating an in-depth subtextual sense base;

- cause and effect attributions (cause effect) - semantical wrongnesses connected with the "speaker's belief that a certain person (or a complex of conditions) could perform a certain action, which, in a certain necessary way, would make the other person feel a certain feeling or inner condition" [3, p. 139], which are usually realized in detailed syntactic structures with the cause-result semantics;

- "mind reading" - a class of semantically incorrect surface structures connected, firstly, "with the speaker's belief that he knows what the other person thinks or feels, without any direct messages about this from the aforementioned person" [ibid, p. 151]; and secondly, with the speaker's being sure that the other person knows what the speaker thinks or feels.

The second science we utilize in order to develop the IWs classification is P. Ekman's Theory of Lies (Psychology of Lies), with the according types of lies. Such a parallel could be drawn considering the main aim of the IW, which is to maintain or totally change the recipient's beliefs and opinions, since the very news blocks represent a certain concentrated charming. Nowadays, the popularity, trustability and "sales index" information provided by the mass media no longer depends on delivering the mandatorily objective, relatable and verified data, instead depending on suggestive techniques having been used, and their outshining the opponent's ones. This gives us a reason to state that the level of the news' (and information they provide) objectiveness and compliance with reality is at the very least exaggerated and distorted, thus making their conceptual tactics and the real state of affairs totally non-identical. That said, the isolation of such a fundamental attribute alone a priori turns it into a substrate characteristic of the discourse as a whole, emphasizing its systematic nature.

P. Ekman defined lies as "an occurrence of one person misleading the other one, and doing that intentionally, without a prior notice about one's goals, and without the victim's clear request not to disclose the truth" [13, p. 21] and identifies its two main forms:

- concealment, when the liar conceals the true information, but doesn't provide the untruthful one, and

- falsification, when the liar not only conceals the true information, but also provides the untruthful one, trying to make it look like truth [ibid].

P. Ekman emphasizes that usually, the liars choose the concealment form, since it is a passive one, and resort to falsification when they are clearly convicted in the fact that they are not telling something. He also notes that usually, only a combination of both concealment and falsification could be qualified as lies, but sometimes the liar could succeed if he / she just doesn't tell the whole truth. Besides, usually, those who tell lies choose the concealment type, since it is a passive one, and only resort to falsification when they clearly expose that they're not telling something. 
On top of that, P. Ekman identifies five more types of lies:

- imitating the emotions the liar doesn't really feel;

- false explanation of the particular emotional state's reasons;

- half-truth (communicative reduction, misunderstandings);

- a confusing trick (P. Ekman defines it as "dodge");

- presenting the truth so that it's impossible to believe it (truth exaggeration) [ibid, p. 21-31].

We consider the latter lies type, as well as the two basic forms, to be relevant for our research, since they could be vividly illustrated within the network of the Metamodel qualification.

Thirdly, the Linguistic Suggestivity NAP-structure has been suggested in our previous scientific researches [see 7]. Being the influential reconstruction psycho-mental and linguistic-structure substrate, it illustrates the suggestant's certain consciousness states, and one's external actions in order to save or change these states. The NAP-structure consists of the following elements:

- N-element ("N" for "negative") - which verbalizes the suggestant's certain "negatively connotated" state, which needs to be changed. It means that the suggestant, consciously or subconsciously, feels a certain discomfort and a need for certain changes, but very often, both the discomfort and the wish for changes are artificially created and inspired by the suggestor;

- A-element ("A" for "action") - which verbalizes a certain action the suggestant has to carry out in order to conquer the negatively connotated state. Surely, sometimes, the suggestant oneself might want to execute this action, but usually, the wish to carry it out is inspired by the suggestor;

- P-element ("P" for "positive") - which verbalizes the suggestant's certain "positively connotated" state one is supposed to be in after having executed the action mentioned in the previous element of the structure. In most cases, the very idea that this state would necessarily manifest itself when the action is executed is artificially inspired by the suggestor, and isn't the product of suggestant's consciousness, which gives reasons to believe that this element is a result of a changed state of consciousness having been implemented.

Erst, this structure manifests itself on the lexical-semantic level, via the certain morphologic units' semantic variation, so that its each element could be expressed both explicitly (verbalized in the text) or implicitly (not verbalized in the text).

Therefore, after having identified the according linguistic construct markers in the network of the first block of the algorithm, it is necessary to move on towards the second block, which is aimed at classifying these elements and relating them to the according information wars types, and could be visualized with a following table. 


\begin{tabular}{|c|c|c|c|}
\hline $\begin{array}{l}\text { Information } \\
\text { war type }\end{array}$ & «Swan Lake» & $\begin{array}{c}\text { «Mountains out of } \\
\text { Molehills» }\end{array}$ & «Fake Attack» \\
\hline \multicolumn{4}{|l|}{ I-block markers } \\
\hline \multirow{2}{*}{$\begin{array}{c}\text { MLM process } \\
\text { and most frequent } \\
\text { markers }\end{array}$} & $\begin{array}{l}\text { Deletion } \\
\text { represented by: }\end{array}$ & $\begin{array}{l}\text { Generalization } \\
\text { represented by: }\end{array}$ & $\begin{array}{l}\text { Distortion } \\
\text { represented by: }\end{array}$ \\
\hline & $\begin{array}{l}\text { - unspecified } \\
\text { vocabulary } \\
\text { (mostly); } \\
\text { - judgements (in } \\
\text { order to } \\
\text { maximally de- } \\
\text { objectificate the } \\
\text { data provided); } \\
\text { - comparative- } \\
\text { superlative } \\
\text { constructions; } \\
\text { - nominalizations } \\
\text { (very rarely). } \\
\quad \text { concealment }\end{array}$ & $\begin{array}{l}\text { - universal } \\
\text { quantifiers } \\
\text { (mostly); } \\
\text { - modal operators } \\
\text { (more rarely). }\end{array}$ & $\begin{array}{l}\text { - «mind reading» } \\
\text { (mostly); } \\
\text { - presuppositions; } \\
\text { - complex } \\
\text { equivalence (more } \\
\text { rarely). }\end{array}$ \\
\hline $\begin{array}{c}\text { NAP-structure } \\
\text { element }\end{array}$ & $\begin{array}{l}\text { Explicated P- } \\
\text { element }\end{array}$ & $\begin{array}{l}\text { Explicated A- } \\
\text { element (used to } \\
\text { state the } \\
\text { generalized } \\
\text { action); } \\
\mathrm{N} \text { - and P-elements } \\
\text { complex, but } \\
\text { without an } \\
\text { emphasis on their } \\
\text { markers' } \\
\text { according negative } \\
\text { or positive } \\
\text { connotation }\end{array}$ & $\begin{array}{l}\text { Explicated N- } \\
\text { element }\end{array}$ \\
\hline
\end{tabular}

Having classified the construct markers, and attributed them to the according IW type in the network of the second block of the algorithm, it is necessary to, in the network of the 
third, final block, choose the according reaction action, which would allow to neutralize of maximally lessen the negative effect of the according pathogenic text. We suggest three basic strategies, which could be identified as the levels of neutralizing such harmful influence, depending on the effect that has to be reached in the network of neutralization.

1. Logical Refutation Strategy (LRS) is a logical operation of establishing the falsity of undergroundedness of the previously mentioned thesis, which is aimed at ruining the accomplished proof, and, depending on the goal of the animadversion, could be either the thesis critique, or arguments critique, or demonstration critique [see 4, 5, 12, 14]. It has to be noted that LRS should be used in order to logically, objectively, factually prove the wrongness of the data provided in the pathogenic text, so it would be maximally effective if used to neutralize the negative effect of "Mountains out of Molehills" IW type (i.e., if a certain event was participated by 10000 persons, and in the network of a pathogenic text, it is stated that the number of the participants reached only up to 1000 persons, then its wrongness might be proved via providing the objective data, such as information by the power structures having registered the participants, or panoramic photos). It should be mentioned that LRS can't be used, for example, to neutralize the "Fake Attack" IW type, considering its thorough falseness.

2. In the network of the Filling the Gaps Strategy (FGS), either the information opposite to the one provided in the network of the pathogenic text is presented, so that the decision of which text is true is left up to the recipient (the target audience); or the information demanded by the recipients and absent in the other sources in the network of "Swan Lake" IW type is provided (i.e., in case of the data about a certain high-ranking official's whereabouts being concealed, aside from the statement of one's being on vacation, information about one's schedule and precise location might be published).

3. Trolling Strategy (TS) could be described as "raising the degree" of the pathogenic texts' fakeness, resulting in a so-called comic and satiric effect, which lowers both the social tension level, and the level of trust in the information provided in the pathogenic text (relatable to the NLP's pattern disruption technique). For example, the pathogenic texts stating that the Ukrainian eat bullfinches, since these birds look like the Russian flag, were reacted to with memes depicting "canned bullfinch", which maximally demonstrated the level of the initial news' insolvency.

Thus, it is safe to state that, since the suggested information wars' pathogenic texts' harmful effect neutralization algorithm combines a comprehensive scientific approach integrating the achievements of such modern sciences as Neuro-Linguistic Programming, Suggestive Linguistics and Lies Theory, utilizing it would allow not only to identify the dominant in-depth construction strategies of the IWs' pathogenic texts, but also to formulate the countermeasures strategies and tactics for each IW type. And this, in its turn, will not only deepen the relevant provisions of NLP, Suggestive Linguistics, Discoursology, Psycholinguistics, and Public Administration studies, but will also help form the according program decisions in the sphere of Ukraine's state informational policy and safety in the state of the hybrid wars, thus maximally visualizing and emphasizing the perspective of the further research within this scientific sphere. 


\section{Literature}

1. Асмолов А.Г. Психология личности: Учебник. - М. : Изд-во МГУ, 1990. $367 \mathrm{c}$.

2. Буч Г. Объектно-ориентированный анализ и проектирование с примерами приложений на $\mathrm{C}++=$ Object-Oriented Analysis and Design with Applications / Пер. И.Романовский, Ф.Андреев. - 2-е изд.- М., СПб. : «Бином», «Невский диалект», 1998. $-560 \mathrm{c}$.

3. Бэндлер Р., Гриндер Д. Структура магии. - СПб.: Белый кролик, 1996. -496 с.

4. Вагапова Д. Х. Риторика в интеллектуальных играх и тренингах. - 2-е изд., стереотип. - М. : Цитадель-трейд, 2001. - 459 с.

5. Вольфенгаген В. Э. Логика. Конспект лекций: техника рассуждений. 2-е изд., дополн. и перераб. - М. : Центр ЮрИнфоР, 2004. - 229 с.

6. Дал У., Дейкстра Э., Хоор К. Структурное программирование. - М. : Мир, 1975. $-247 \mathrm{c}$.

7. Ковалевська A. В. Реклама та PR у масовоінформаційному просторі / Реклама та PR у масовоінформаційному просторі: монографія / [Ковалевська Т. Ю., Кондратенко Н. В., Кутуза Н. В., П Порпуліт О. О., Ковалевська А. В.]: за заг. ред. О. В. Александрова; відп. ред. Т. Ю. Ковалевська, Н. В. Кутуза. - Одеса : Астропринт, 2009. - $400 \mathrm{c}$.

8. Ковалевська Т. Ю. Комунікативні аспекти нейролінгвістичного програмування : Монографія. - Одеса : Астропринт, 2001. - 324 с.

9. О’Коннор Дж., Сеймор Дж. Введение в НЛП. - Челябинск : Версия, 1997. $256 \mathrm{c}$.

10. Присяжнюк М., Жарков Я. Аналіз засобів ведення інформаційної боротьби 3 використанням інформаційних технологій, форм і способів їх застосування. URL : http://defpol.org.ua/site/index.php/uk/component/content/article/51-kolonkaavtora/5610082009

11. Смит C. Жесткая книга о том, как убедить, загипнотизировать, заставить кого угодно. Маленькая книга сильнейших примов гипноза и воздействия. - М.: АCT, 2010. $-224 \mathrm{c}$.

12. Халперн Д. Психология критического мышления. - СПб. : Питер, 2000. $512 \mathrm{c}$.

13. Экман П. Психология лжи. Обмани меня, если сможешь. - СПб. : Питер, 2010. $-304 \mathrm{c}$.

14. Hurley Patrick J. A. Concise Introduction to Logic. - Boston, USA : Wadsworth Publishing, 2011. $-707 \mathrm{p}$.

15. Kovalevska A. Information Warfare in the State's Security Policy / Scientific Annals of "Alexandru Ioan Cuza" University of Iasi (New Series) POLITICAL SCIENCE. Vol. 12, No. 1 (2017) : Political Sciences, Tome XII, 2017. - Iasi, Romania - 2017. - Access mode : http://anale.fssp.uaic.ro/index.php/stiintepolitice/article/view/504 
16. Kovalevska A. Verbal Influence in the Information Wars: Identifying the Suggestive Patterns / Записки з українського мовознавства : Вип. 24. У 2-х томах. - Т. 2. : Зб. наук. праць $=$ Opera in linguistica ukrainiana: Fascicullum 24. - Vol. 2 / Головний ред. Т. Ю. Ковалевська. - Одеса: «ПолиПринт», 2017 - С. 231-257.

\section{References}

1. Asmolov, A. G. (1990), Psychology of the Individual [Psikhologiya lichnosti], MGU, Moscow, $367 \mathrm{p}$.

2. Booch, G. (1998), Object-Oriented Analysis and Design with Applications [Ob'ektno-orientirovannyj analiz i proektirovanie s primerami prilozhenij na $\mathrm{C}++$ ], Binom, Nevskij dialect, Moscow, St.-Petersburg, 560 p.

3. Bandler, R., Grinder, R. (1996), Structure of Magic [Struktura mahyy], Belyy krolik, St.-Petersburg, 496 p.

4. Vagapova, D. H. (2001), Rhetorics in Individual Games and Trainings [Ritorika v intellektual'nyh igrah i treningah], Citadel'-trejd, Moscow, 459 p.

5. Vol'fengagen, V. E. (2004), Logics. Lectures Notes: Reasoning Techniques [Logika. Konspekt lekcij: tehnika rassuzhdenij], “Centr JurInfoR” JSC, Moscow, 229 p.

6. Dahl, W., Dijkstra, E., Hoor, K. (1975), Structured Programming [Strukturnoe programmirovanie], Mir, Moscow, $248 \mathrm{p}$.

7. Kovalevska, A. V. (2009), Advertisement and PR in Mass Information Space [Reklama ta PR u masovoinformacijnomu prostori], Astroprynt, Odesa, $400 \mathrm{p}$.

8. Kovalevska, T. Y. (2001), Communicative Aspects of Neurolinguistic Programming [Komunikatyvni aspekty neyrolinhvistychnoho prohramuvannya], Odesa, Astroprint, $344 \mathrm{p}$.

9. O'Connor, J., Seymour, J. (1997), Introducing NLP [Vvedenie v NLP], Versiya, Chelyabinsk, 1997.

10. Prysyazhnyuk, M., Zharkov, Y. (2014) Analysis of the Information Fight Means with the Help of Information Technologies, Forms and Their Application Means [Analiz zasobiv vedennya informatsiynoyi borot'by $z$ vykorystannyam informatsiynykh tekhnolohiy, form sposobiv yikh zastosuvannya], http://defpol.org.ua/site/index.php/uk/component/content/article/51-kolonkaavtora/5610082009

11. Smit, S. (2010), Hard book on How to Convince, Hypnotize, Compel Anyone. Little Book of the Strongest Hypnosis and Influence Techniques [Zhestkaya kniga o tom, kak ubedit', zagipnotizirovat', zastavit' kogo ugodno. Malen'kaya kniga sil'neyshikh primov gipnoza i vozdeystviya], AST, Moscow, $224 \mathrm{p}$.

12. Halpern, D. (2000), Critical Thinking Psychology [Psihologija kriticheskogo myshlenija], Piter, St.-Petersburg, 512 p.

13. Ekman, P. (2010), Psychology of Lies. Lie to Me if You Can [Psikhologiya lzhi. Obmani menya, esli smozhesh'], Piter, St.-Petersburg, 304 p.

14. Hurley, Patrick J. A (2011), Concise Introduction to Logic, Wadsworth Publishing, Boston, USA, 707 p. 
15. Kovalevska, A. (2017), Information Warfare in the State's Security Policy, Scientific Annals of "Alexandru Ioan Cuza" University of Iasi, Iasi, No. 12, http://anale.fssp.uaic.ro/index.php/stiintepolitice/article/view/504

16. Kovalevska A. (2017), Verbal Influence in the Information Wars: Identifying the Suggestive Patterns, Zapy`sky`z ukrayins`kogo movoznavstva, Odesa, No. 24, pp. 231-257.

\section{А. В. Ковалевська,}

Одеський регіональний інститут державного управління Національної академії державного управління при Президентові України, кафедра проектного менеджменту

\section{ААГОРИТМ НЕЙТРААІЗАЦÏ̈ ПАТОГЕННИХ ТЕКСТІВ IНФОРМАЦІЙНИХ ВОЄН}

Статтю присвячено вивченню негативного ефекту феномену мовленнєвого впливу, який реалізується у патогенних текстах, поширюваних в українському інформаційному просторі в рамках інформаційних воєн. Основна мета інформаційної війни, яка полягає в підтримці або зміні політичних уподобань адресата, передбачає нетотожність, викривленість інтерпретації об'єктивної реальності як ії фундаментальну ознаку, тож величезної важливості, особливо за умов сучасної соціально-політичної ситуації, що склалася в Україні, набуває не лише питання систематизації інформаційних воєн як вкрай потужного феномена сучасного інформаційного простору країни, а й проблема формулювання стратегій і тактик протидії негативному впливу, продукованому патогенними текстами в рамках IB, що і визначає актуальність роботи, скерованої на конструювання алгоритму нейтралізації негативного ефекту патогенних текстів, наявних у парадигмі інформаційних воєн. Дослідження виконано в парадигмі таких комплексних новітніх наук як нейролінгвістичне програмування i сугестивна лінгвістика і становить собою покроковий алгоритм нейтралізації шкідливого ефекту патогенних текстів, базований на виокремленні маркерів сугестивних технік, описаних в метамоделі мови НЛП, теорії брехні П. Екмана, авторській класифікації інформаційних воєн, а також авторській NAP-структурі лінгвістичної сугестивності, а також елементах об'єктно-орієнтованого та структурного програмування і загальної логіки (доведення та спростування), тож, він дасть змогу не лише виокремити домінантні стратегії побудови зазначених патогенних текстів та глибинні механізми їх конструювання, а й способи протидії кожному 3 типів інформаційних воєн, що прислужиться не лише у поглибленні відповідних положень НЛП, сугестивної лінгвістики та психолінгвістики, а й у можливому формуванні відповідних планувальних рішень в галузі державної інформаційної безпеки України, що максимально увиразнює релевантність та перспективність подальших розвідок у зазначеній науковій царині.

Ключові слова: інформаційна війна, вплив, мовленнєвий вплив, сугестія, нейролінгвістичне програмування, НЛП, сугестивна лінгвістика, теорія брехні, 
метамодель мови, патогенні тексти, алгоритм, NAP-структура лінгвістичної сугестивності.

\section{А. В. Ковалевская, \\ Одесский региональный институт государственного управления Национальной академии государственного управления при Президенте Украинь, кафедра проектного менеджмента}

\section{ААГОРИТМ НЕЙТРАМИЗАЦИИ ПАТОГЕННЫХ ТЕКСТОВ ИНФОРМАЦИОННЫХ ВОЙН}

Статья посвящена изучению негативного эффекта феномена речевого воздействия, который реализуется в патогенных текстах, распространяемых в украинском информационном пространстве в рамках информационных войн. Исследование выполнено в парадигме таких комплексных новейших наук как нейролингвистическое программирование и суггестивная лингвистика и представляет собой пошаговый алгоритм нейтрализации вредного эффекта патогенных текстов, основанный на выделении маркеров суггестивных техник, описанных в метамодели языка НЛП, теории лжи П. Экмана, авторской классификации информационных войн, а также авторской NAP-структуре лингвистической суггестивности.

Ключевые слова: информационная война, влияние, речевое воздействие, суггестия, нейролингвистическое программирование, НЛП, суггестивная лингвистика, теория лжи, метамодель языка, патогенные тексты, алгоритм, NAP-структура лингвистической суггестивности. 